\title{
ADOPTION OF COCONUT-BASED INTERCROPPING SYSTEMS IN SRI LANKA: THE FALLACY OF CONVENTIONAL WISDOM ON ECONOMIC PROFITABILITY
}

\author{
By \\ M.T.N. Fernando ${ }^{12}$ M. E. Daw $^{2}$ \& I. E. Edward ${ }^{2}$
}

\begin{abstract}
Despite the concerted efforts of successive governments in Sri Lanka to popularize coconutbased intercropping (CBI) systems, an intensive land use alternative to traditional less intensive coconut monocropping, its adoption by farmers is as low as $25 \%$ of the agronomically potential area of 100,000 ha. Although the adoption of an innovation is influenced by a range of determinants which can be broadly categorized as technical, economic, institutional and personal/social, economic profitability of the technology itself is one of the key determinants influencing its adoption. This study assesses the economics of widely practiced five different CBI systems vis-a-vis coconut monocropping, employing five economic indicators, namely Total Gross Margin (TGM), Net Present Value (NPV), Benefit-Cost Ratio (BCR), returns to labor and returns to capital. Data were collected by a field survey of 113 intercroppers and 37 monocroppers conducted from March to May 1995 in three main coconut growing districts in Sri Lanka, namely: Gampaha; Kurunegala; and, Puttalam. Results revealed that all the CBI systems give higher returns per hectare than coconut monocrops, though some of the indicators, namely BCR and returns to variable costs, are reasonably attractive for monocrop coconuts, albeit they are less than for some CBI systems. The study concluded that the low rate of adoption of CBI systems is not a problem of low profitability. Hence, it is worthwhile to explore the other factors typically influencing the adoption of production technologies to find out the reasons for low adoption of CBI
\end{abstract}

\section{INTRODUCTION}

Coconut is indispensable to Sri Lanka mainly because of its intimate integration into the daily diet of Sri Lankans. The coconut industry contributes about 2.7 and 3.3\%, to the Gross Domestic Product (GDP) and to export earnings, respectively, while providing livelihood for some 400,000 rural families (Liyanage, 1997). As is well known, coconuts are cultivated predominantly as a monocrop in almost all coconut growing countries in the world including Sri Lanka. Since coconuts have to be planted at wider spacing to permit the canopy growth at maturity (Figure 1), monocrop coconuts utilize bio-physical resources sub-optimally. A mature coconut palm in a pure coconut stand utilizes only about $25 \%$ of the soil mass, leaving some $75 \%$ of the soil unutilized or under utilized (Fernando, 1997). A mature coconut palm during the 6-hour peak brightest period of the day (i.e. 10:00 to 16:00 hours) intercepts effectively only about $44 \%$ of the total solar radiation, the remaining 56\% of solar radiation being unutilized (Nair and Balakrishnan, 1976). In terms of land use, coconut is the largest plantation crop occupying 416,000 ha which is about $20 \%$ of nation's cultivable lands, and is approximately equal to the collective area occupied by tea and rubber, the other two major plantation crops. Inefficient land use by monocrop coconuts involves a foregone opportunity cost of an intensive land use alternative. Intercropping monoculture coconut lands with annuals, semi-perennials and perennials, raising livestock or intercropping-livestock integration under coconuts intensify the less efficient land use of coconut monocropping, thereby raising farmer's income. Despite state efforts in terms of providing subsidies, low-interest loans, extension

1 Coconut Research Institute, Lunuwila, Sri Lanka;

2 Department of Agriculture, University of Aberdeen, Scotland, UK, respectively. 
support, etc. to popularize coconut-based intercropping (CBI) over two decades, its adoption by farmers is still as low as $25 \%$ of the agronomically potential area of 100,000 ha.

Figure 1. Structure of coconut canopy at different ages
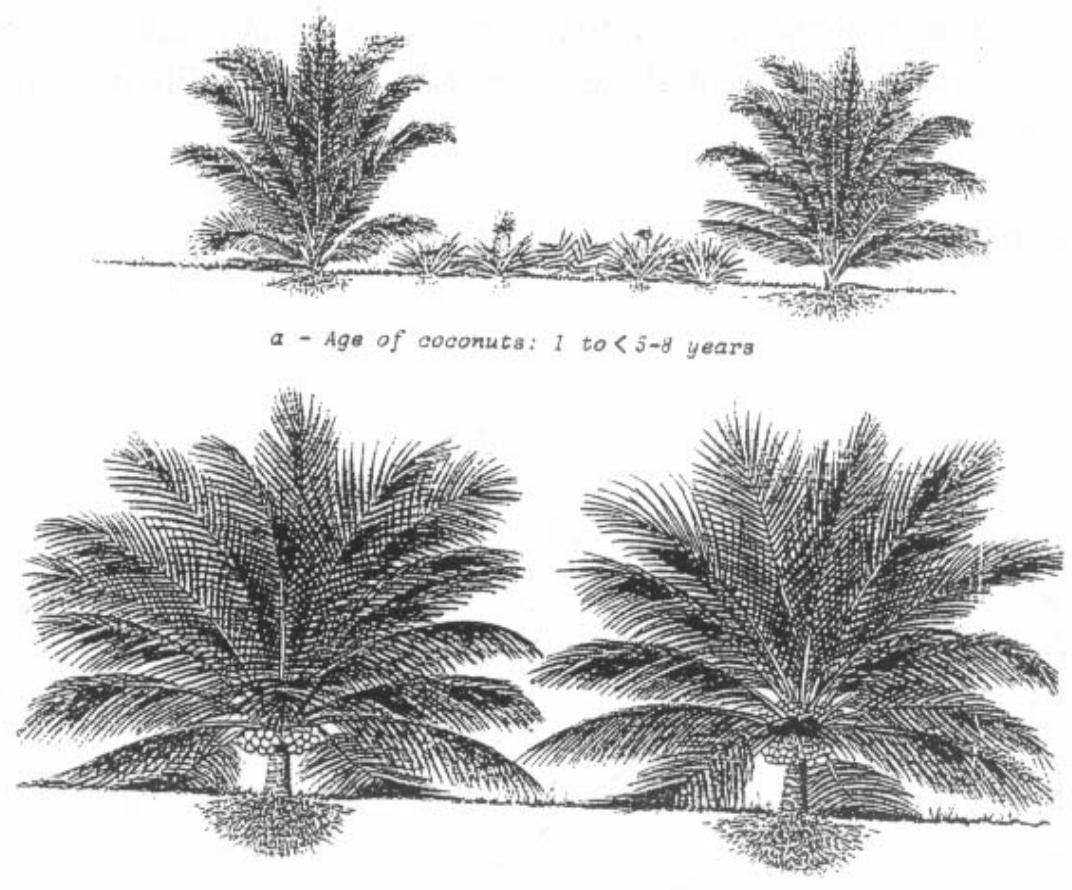

$b$ - Ags of coconuts: $5-8$ to $20-25$ years

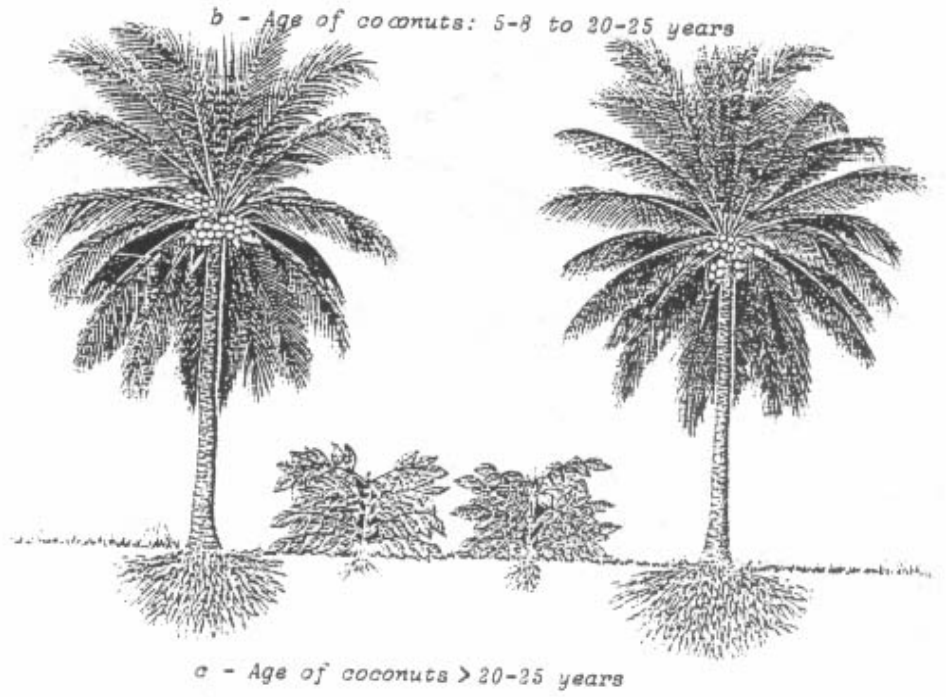

Notes a - Light and soil ars sub-optimaliy utilised. Intercropping is feasible.

$b$ - Intermedicte stage of palms. Intersopping is not feasible.

- Ligint and soil are sub-optimalty utilised. Intercropping is
feasible.

Source ddapted from Nahindapaia and Pinto (1592). 79 p. 


\section{Theory of Adoption of an Innovation}

As show in Figure 2, a range of factors, which could be broadly categorized as technical, economical institutional, and personal/social, influences the adoption of an innovation.

\section{Figure 2 Determinants of adoption of an innovation}

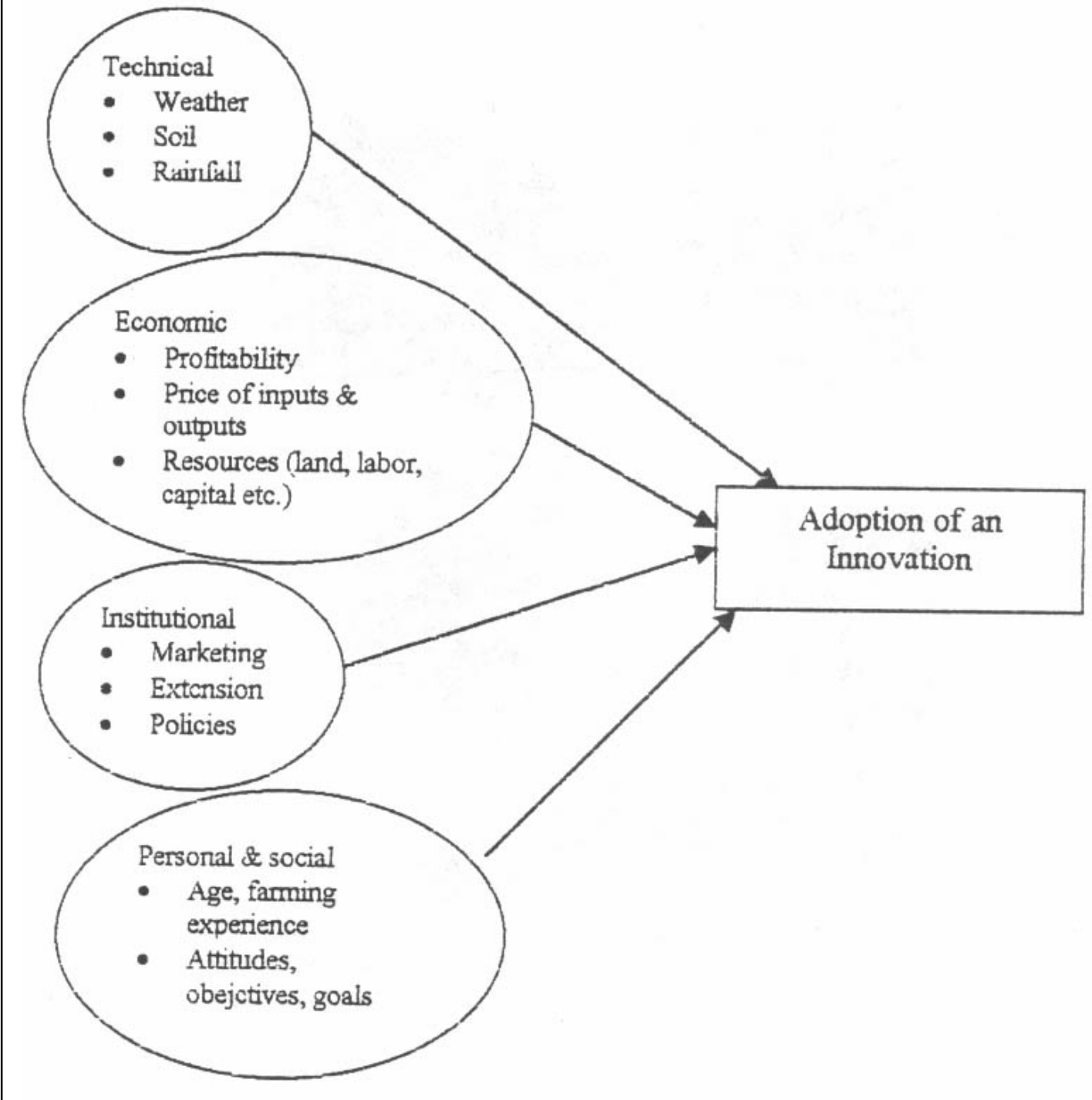

Among the factors shown in Figure 2, the economic profitability of a technology is one of the key determinants influencing its adoption by farmers. The objective of this paper is to assess the economics of existing CBI systems. More specifically, this study determines the economics of widely practiced five different CBI systems in relation to coconut monocropping.

\section{Hypothesis:}

Maintenance of existing mature coconut lands as monocrop is economically worthwhile in relation to intensifying them as CBI systems. 


\section{METHODS}

Data: A farmer survey was carried out from March to May 1995 to collect the data.

Sample size: The sample comprises 113 coconut-based intercroppers and 37 coconut monocroppers

Survey area: Three main coconut-growing districts in Sri Lanka, namely: Gampaha; Kurunegala; and, Puttalam constitute the survey area.

Sampling Procedure: Although these districts comprise five agro-ecological regions, namely $\mathrm{IL}^{1}$, $\mathrm{WL}^{2}, \mathrm{WL}^{4}$ and $\mathrm{WM}^{3}$, a greater percentage $(86 \%)$ of Coconut Development Officer (CDO) ranges ${ }^{1}$ fall in the $\mathrm{IL}_{1}$ and $\mathrm{WL}_{3}$, and hence only the $\mathrm{CDO}$ ranges falling in $\mathrm{IL}_{1}$ and $\mathrm{WL}_{3}$ were purposively selected for the survey. The land area of the above three districts falling under IL1 agro-ecological region is greater than that of $\mathrm{WL}_{3}$. Hence, about $60 \%$ of sampling units $(22$ monocroppers and 68 intercroppers) were allocated into $\mathrm{WL}_{3}$ (Table 1).

Table 1. Allocation of sampling units

\begin{tabular}{|l|c|c|c|}
\hline & \multicolumn{3}{|c|}{ Agro-ecological regions* } \\
\hline & $\mathrm{IL}_{1}$ & $\mathrm{WL}_{3}$ & Total \\
\hline Monocroppers & 22 & 15 & 37 \\
\hline Intercroppers & 68 & 45 & 113 \\
\hline Total & 90 & 60 & 150 \\
\hline
\end{tabular}

Sampling units were allocated in each CDO range as follows.

- Agro-ecological regions are categorized based mainly on 75\% expectancy value of annual rainfall. Major soil groups and terrain characteristics are also considered for the categorization.

$I L_{1}-\quad:$ Low-country Intermediate zone 1

$W L_{2} \quad$ : Low-country Wet Zone 2

$\mathrm{Wl}_{3} \quad$ : Low-country Wet Zone 3

$W_{4} \quad$ : Low-country Wet Zone 4

$W M_{3} \quad$ : Mid-country Wet Zone 3

Table 2 Distribution of monocroppers and intercroppers in CDO ranges

\begin{tabular}{|l|c|c|l|l|c|}
\hline \multicolumn{7}{|c|}{ Agro-ecological region } \\
\hline \multicolumn{1}{|c|}{ CDO range } & Monocroppers & Intercroppers & CDO range & Monocroppers & Intercroppers \\
\hline Dummalasuriya & 2 & 8 & Nittambuwa & 2 & 7 \\
Kuliyapitiya & 2 & 7 & Mirigama & 2 & 7 \\
Welpalla & 2 & 7 & Pallewela & 3 & 8 \\
Yackwila & 3 & 8 & Minuwangoda & 3 & 8 \\
Dambadeniya & 2 & 7 & Urapola & 3 & 8 \\
Weerambugedara & 2 & 7 & Weke & 2 & 7 \\
Udubaddawa & 3 & 8 & & & \\
Dankotuwa & 3 & 8 & & & \\
Hamangalla & 3 & 8 & & & \\
\hline Total & 22 & 8 & & 15 & 45 \\
\hline
\end{tabular}




\section{Analysis}

A range of economic indicators is available to measure the relative advantage/disadvantage of a new technology. The importance of each economic indicator for this study and the calculation procedure are outlined below.

Total Gross Margin (TGM)

Annual TGM analysis provides an estimate of the sum of annual net cash flows in the intercrop and monocrop systems. The annual gross output quantities of each product were priced to derive the annual gross income, and deducting the variable costs (see Appendix Tables A1 to A5) derived annual gross margins.

Net Present Value (NPV)

Coconut is a perennial crop and most of the other intercrops observed in the field are semiperennial crops. The costs and benefits of such crops occur at different times and, therefore, a measure is required to compare the net worth of the monocrop and integrated system over the entire production period. NPVs are employed to meet this objective. The credit scheme of the Perennial Crops Development Project (PECRODEP) which is widely operating through its Participatory Credit Institutes provides loans at $15 \%$ interest rate, so a $15 \%$ interest rate was used for NPV calculations. A sensitivity analysis is also carried out at 20 and $25 \%$.

\section{Benefit-Cost Ratio (BCR)}

This measures the returns in relation to the invested sums. The sum of the discounted benefits was divided by the sum of the discounted costs to derive the BCR.

\section{Returns to Variable Costs}

This economic indicator measures the efficiency of the production system with respect to the variable costs involved. Returns to variable cost were computed by dividing the annual gross farm income by the annual farm variable costs.

\section{Returns to Labor}

Labor productivity is an important consideration in smallholder agriculture. Returns to labor measured in Rupees per man-day was employed to investigate the relative returns provided by the monocrop and intercropping systems. Non-labor inputs were deducted from the gross farm income in each year, and the result was divided by the total labor use in man-days over the whole season to drive the returns to labor.

The above indicators are separately computed for monocrops as well as intercropping systems.

\section{RESULTS AND DISCUSSION}

\section{(A) Economic analysis of existing coconut monoculture systems}

The economic analysis of existing coconut monoculture system will be carried out in this section using the above indicators for coconut monoculture system. The testable hypothesis of this analysis is whether the maintenance of existing mature coconut lands, as monocrops is economically worthwhile than introducing coconut-based intercropping (CBI). The inclusion of the establishment 
costs of monocrop coconuts would not be helpful in testing this hypothesis, as they are historical (sunk) costs (Famiyeh, 1971). Therefore, only the annual maintenance costs of monocrop coconuts wee included in the calculation.

\section{a) TGM (Total Gross Margin)}

Annual input and output data with respect to existing mature coconut monoculture system of the sample farmers were used to derive the total gross margin of coconut monocrop system. Liyanage et al. (1988) found that the nut yield of Sri Lanka Tall (SLT) palms increases progressively every year after initial bearing until a maximum ${ }^{2}$ is attained at about 16-18 years, and is maintained thereafter depending on the environmental conditions. The average age of the coconut palm in the sample was 41 years and the annual average nut yield was 2946 nuts/acre/year (7277 nuts/ha/year). It could be argued that the representative monocrop stand of the survey sample has already achieved the maximum yield. Therefore, the average yield of 2946 nuts per acre per year would be expected to continue during each year of the entire five years ${ }^{3}$ of planning horizon considered for the comparison with the intercropping systems. Table 3 shows the sample average gross margin (Rs/ac/year) of the matured coconut monoculture system.

\section{NPV (Net Present Value) and BCR (Benefit-Cost Ratio)}

Constant annual variable costs and gross returns for the entire period of five years were considered to calculate the NPV and BCR of monoculture system (see Appendix Table A6). The calculated NPVs of GMs are Rs. 20,364; Rs. 18,168, and Rs. 16,337 at 15; 20; and 25\% discount rates, respectively. The BCR is 2.87 .

\section{b) Returns to Labor}

This was calculated to be Rs 656 per man day (Appendix Table A6)

\section{c) Returns to Variable Costs}

In coconut monoculture systems, this is the same as the BCR (2.87), as it assumes constant annual: a) variable costs and b) gross returns, for the entire five-year period. These results are compared with the corresponding results of CBI systems in the next section to test the relevant hypothesis.

2 The maximum yield is about 3,000 to 4,000 nuts per acre depending on soil, environment and management conditions (Liyanage et al. 1988)

3 The reason for considering a five-year period for this comparison is as follows: Monoculture coconuts in the present sample have already achieved the maximum yield and therefore the sample average yield of 2,946 nuts/ac/year will be consistent throughout the rest of the palm life. On the other hand, the input requirements' including labor does not vary much over the years once monocrop coconuts attain the maximum yield. This implies that the TGM of coconut monocrops does not vary over the rest of the palm life given the constant prices used for calculations throughout. Hence, the number of years required for the comparison of monocrop with intercropping systems is dictated by the number of years required by intercrops for an effective comparison. Five years would be sufficient for the comparison because the economic life of semi-perennial intercrops considered is five years. 
Table 3 Calculation of annual gross margin (Rs/acre) of coconut monoculture system

\begin{tabular}{|l|r|}
\hline \multicolumn{1}{|c|}{ OUTPUT } & \\
No. of nuts (per acre/year & 2946 \\
Average price (Rs/nut) & 3.16 \\
Gross Return (Rs) & 9309.36 \\
\hline INPUTS & \\
Labor use (man days) & 5.5 \\
Weeding & 3 \\
Fertilizer application & 2.5 \\
Nut collection & 11 \\
Total man days & 104 \\
Average wage rate (Rs/man day) & 582 \\
Contract labor cost for harvesting (Rs/ac) & 1726 \\
\hline Sub-total 1 - labor cost (Rs) & 12.5 \\
\hline Material Cost & 8.5 \\
Fertilizer (kg/ac) & 1062.5 \\
Price (Rs/kg) & 1062.5 \\
Fertilizer cost (Rs) & \\
\hline Sub total 2 materials cost (Rs) & 208 \\
\hline Transport Cost & 238 \\
Fertilizer transport (Rs) & 446 \\
\hline Cost for internal field transportation of coconut (Rs) & 3234.5 \\
\hline Sub total 3 transport cost (Rs) & $\mathbf{6 0 7 4 . 8 6}$ \\
\hline Variable costs (Rs/ac) & \\
\hline Gross Margin (Rs/acre/year & \\
\hline
\end{tabular}

Note: Ave. age of coconut palms - 41 years Source: Farmer Survey, 1985

\section{(B) Economic Analysis of Existing Coconut-Based Intercropping Systems}

The survey has identified an array of different intercropping systems involving various combinations of intercrops, and the relative abundance of each system is shown in Table 4.

Only the first five intercropping systems of the Table 4 namely: coconut + pineapple + banana; coconut + banana; coconut + pineapple; coconut + betel; and, coconut + betel + banana were used for the economic analysis in view of their widespread practice. Other intercropping systems are relatively less significant. All the five economic indicators, as in the case of monoculture systems, have been calculated for the five different intercropping systems considered. While full details of the calculation procedure are found in Appendix Tables A7, A8, A9, A10 and A11 for the five different intercropping systems, respectively, their summary results are compared here with the results of the monoculture system.

Table 4. Relative abundance of different intercropping systems

\begin{tabular}{|l|l|c|c|}
\hline No. & \multicolumn{1}{|c|}{ Cropping system } & Number of farmer practisin & Percentage \\
\hline 1 & Coconut + pineapple + banana & 30 & 2.50 \\
2 & Coconut + banana & 15 & 13.27 \\
3 & Coconut + pineapple & 14 & 12.39 \\
4 & Coconut + betel & 7 & 6.19 \\
5 & Coconut + betel + banana & 6 & 5.31 \\
\hline
\end{tabular}




\begin{tabular}{|c|c|c|c|}
\hline 6 & Coconut + pepper & 4 & 3.54 \\
\hline 7 & Coconut + pineapple + pepper & 4 & 3.54 \\
\hline 8 & Coconut + pineapple + banana + ginger & 4 & 3.54 \\
\hline 9 & Coconut + ginger + banana & 3 & 2.65 \\
\hline 10 & Coconut + ginger + banana + betel & 3 & 2.65 \\
\hline 11 & Coconut + banana + pepper + coffee & 3 & 2.65 \\
\hline 12 & Coconut + pepper + banana & 2 & 1.77 \\
\hline 13 & Coconut + banana + rambutan & 2 & 1.77 \\
\hline \multirow[t]{2}{*}{14} & Other systems & 16 & 14.15 \\
\hline & Total & 113 & 100.00 \\
\hline
\end{tabular}

a) $T G M$

Table 5 and Figure 3 show the annual gross margins of different intercropping systems in comparison with monocrop system.

Table 5. Annual TGM of different cropping systems

\begin{tabular}{|l|r|r|r|r|r|}
\hline \multicolumn{7}{|c|}{ Cropping system } & \multicolumn{1}{|c|}{ Year 1 } & Year 2 & Year 3 & Year 4 & Year 5 \\
\hline \multicolumn{7}{|c|}{ TGM/ac) } \\
\hline Monocrop & 075 & 075 & 6,075 & 6,075 & 6,075 \\
Coconut + pineapple + banana & $-15,263$ & 94,077 & 100,420 & 72,621 & 40,398 \\
Coconut + banana & 10,451 & 32,040 & 28,938 & 2,213 & 16,933 \\
Coconut + pine apple & $-31,061$ & 7,455 & 76,874 & 56,241 & 29,351 \\
Coconut + betel & 28,869 & 85,693 & 111,045 & 73,193 & 49,625 \\
Coconut + betel + banana & 22,057 & 72,058 & 81,632 & 55,904 & 38,969 \\
\hline
\end{tabular}

Figure 3 Annual TGM of different cropping systems

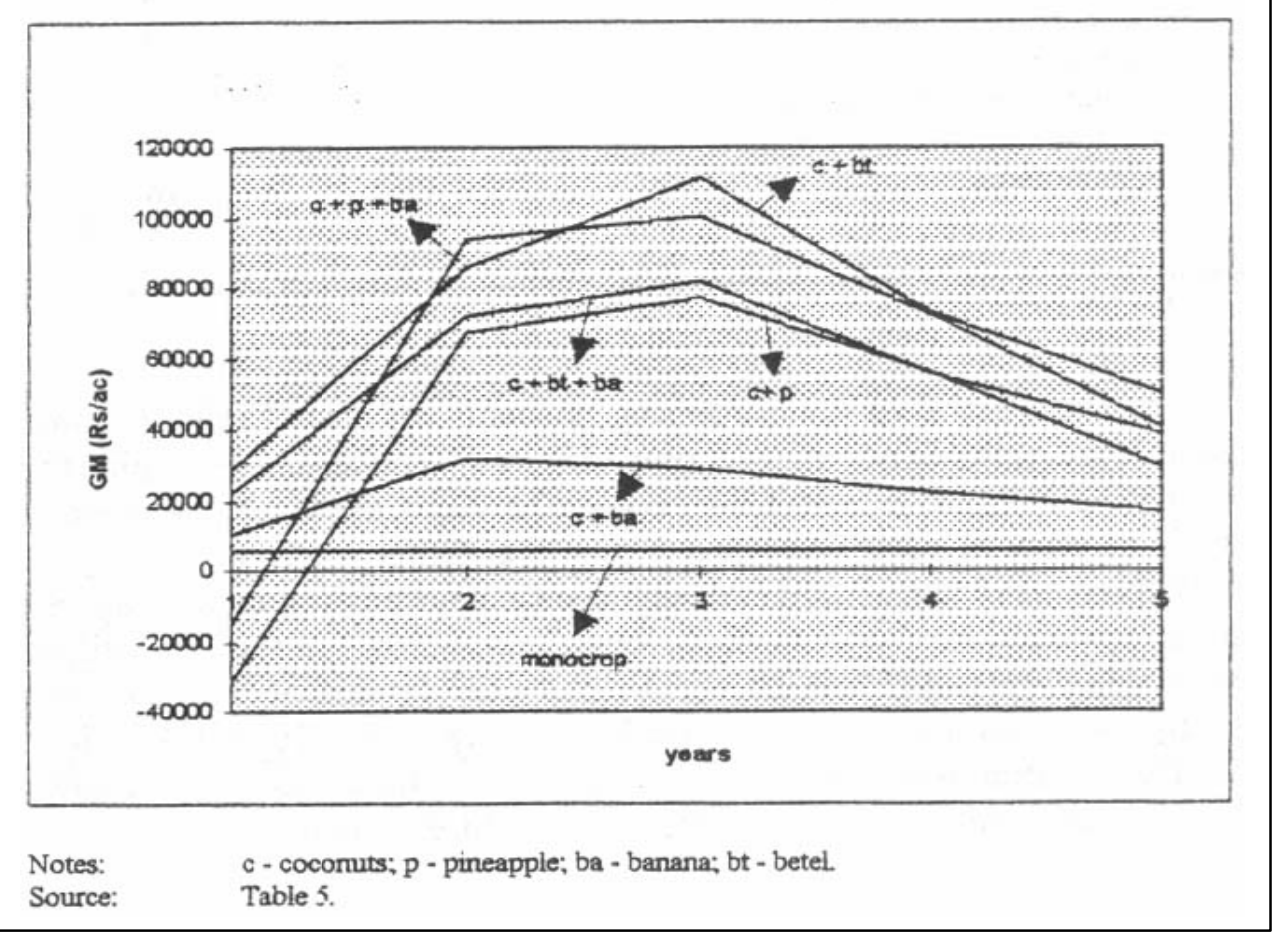


It is clear that the cropping systems comprising pineapple has negative gross margins in the first year, as pineapple does not generate returns in the first year but incurs high costs of establishment. However, it commences to produce much higher gross margins that the monocrop system from the second year onwards.

Cropping systems consisting of betel and banana generate higher positive gross margins compared to monocrop system in the first year of establishment, as these crops commence to yield in the first year. In summary, the annual gross margin analysis suggests that all the intercropping systems considered are superior to monocrop systems in terms of margins per unit of land. Among them, banana and betel systems are more attractive in terms of providing positive annual gross returns during the entire planning period of five years while pineapple systems have a little longer waiting period. The poorly endowed/resource-poor farmers may be much concerned with sustaining a positive annual cash flow, no matter how low rather than waiting longer to obtain higher cash flows. The better endowed/resourceful farmers may be better able to await for higher returns occurring at later stages. NPV, rather than the TGM analysis, would be a better criterion to investigate the appropriateness of cropping systems for the latter group of farmers.

b) $\quad N P V$

NPVs generated by all the intercropping systems are markedly higher compared to the coconut monocrop system at all the interest rates addressed (Table 6). The coconut + betel system yielded the highest NPV. The descending order of NPV of other cropping systems is: coconut + pineapple + banana; coconut + betel + banana; coconut + pineapple and coconut + banana .

Table 6. NPV of different cropping systems over five years (Rs/ac)

\begin{tabular}{|l|r|r|r|}
\hline \multirow{2}{*}{\multicolumn{1}{|c|}{ Cropping system }} & \multicolumn{3}{|c|}{ NPV (Rs) } \\
\cline { 2 - 4 } & $15 \%$ & \multicolumn{1}{c|}{$20 \%$} & \multicolumn{1}{c|}{$25 \%$} \\
\hline Monocrop & 20,364 & 18,168 & 16,337 \\
Coconut + pineapple + banana & 185,498 & 161,982 & 142,397 \\
Coconut + banana & 73,417 & 65,186 & 58,298 \\
Coconut + pineapple & 121,291 & 104,365 & 90,336 \\
Coconut + betel & 229,434 & 20,309 & 18,103 \\
Coconut + betel + banana & 178,678 & 158,282 & 14,122 \\
\hline
\end{tabular}

Notes: $a, b, c$ are discount rates.

Source: Farmer survey, 1995.

As shown by Table 5, the cropping systems involving pineapple has negative gross margins in the first year whereas the gross margins of monocrop system are positive in all the five years considered $^{4}$. It may therefore be argued that the NPVs of intercropping systems involving pineapple would be lower than those for the coconut monocrops at discount rates beyond the ones addressed in Table 6. Hence, a much higher discount rate $(100 \%)$ was used to test the sensitivity of NPVs of intercropping systems having pineapple as a component crop. The resultant NPVs were: Rs 5,885; Rs34,241; and, Rs 5,375, respectively for monocrop coconuts, coconut + pineapple + banana system, and coconut + pineapple system. In addition, the NPV of the monocrop system was also compared with the NPVs of the remaining three other intercropping systems at $100 \%$ discount rate. Coconut + banana; coconut + betel; and, coconut + betel + banana systems, respectively generated Rs 18,765 ; Rs55,864; and, Rs43,959 as against the monocrop NVP of Rs5,885.

4 Coconuts also produced negative gross margins in the first few years of establishment. However, this concern requires no consideration here, because the establishment costs can be considered as historical costs as has been discussed. 
These results prove beyond reasonable doubt that no matter how high the discount rates, the monocrop coconuts are not competitive with any of the other five intercropping systems in terms of providing higher NPVs. The relatively low returns generated by monocrop coconuts are one of the main problems of maintaining coconuts as a monocrop today. This already held view by researchers and farmers were confirmed by the present finding.

c) $\quad B C R$

BCRs were calculated for the five different cropping systems as shown in Table 7.

Table 7 BCRs of Different Cropping Systems

\begin{tabular}{|l|l|}
\hline \multicolumn{1}{|c|}{ Cropping systems } & BCR \\
\hline Monocrop & 2.87 \\
Coconut + pineapple + banana & 3.24 \\
Coconut + banana & 3.07 \\
Coconut + pineapple & 2.74 \\
Coconut + betel & 1.88 \\
Coconut + betel + banana & 2.12 \\
\hline
\end{tabular}

Source: Farmer survey, 1995

The procedure to accept or to reject any project based on BCR criterion, is to accept all those having BCRs greater than unity while rejecting all projects having BCRs lower than unity. Based on this criterion, it is clear that all the cropping systems are financially worthwhile to individual farmers. Perhaps, the most noticeable point is that the coconut monocrop systems exhibit higher BCRs than 3 of the 5 intercropping systems. Coconut monocrop systems utilize less inputs, for instance, less labor and other paid costs for fertilizers etc., but generate benefits more than double in financial terms, indicating that it is a profitable crop. Clearly, the problem of monoculture coconut is not that the return to investment is low, but rather that it generates lower returns per unit of land to growers as evidenced by the previous NPV calculations. Although the coconut + betel system generates the highest NPV/acre compared to other cropping systems (see the results of the NPV calculations in the previous section), the return to investment of this system is the lowest (1.88) compared to the other systems. The reason for this is higher labor inputs required for betel cultivation (labor was valued at market wage rate to compute BCRs). However, betel is an attractive crop for families having high levels of family labor supply. In summary, the BCR analysis reveals that all the cropping systems are financially worthwhile in terms of returns to investment. Of them, the highest BCR was observed in coconut + pineapple + banana system (3.24) while coconut monocrop system also exhibits an attractive BCR (2.87).

\section{d) Returns to family labor}

The returns to family labor generated by different cropping systems were compared with the wage rate of an agricultural laborer, and the returns to family labor of monocrop coconuts were compared with that of the other intercropping systems (Table 8).

The monocrop as well as all the intercropping systems generate markedly higher returns to family labor compared to the average wage rate of an agricultural laborer. From the second year onwards, coconut + pineapple + banana, coconut + pineapple and coconut + banana systems generate substantially higher returns to labor than coconut monocrop system. However, intercropping systems involving betel produces lower returns to labor compared to monocrop systems because betel is a highly labor-intensive crop requiring almost daily labor involvement. Figure 4 shows the return to labor of different cropping systems, and compares these with the wage rate of an agricultural laborer. 
Table 8. Returns to family labour in different cropping systems

\begin{tabular}{|l|r|r|r|r|r|}
\hline \multicolumn{1}{|c|}{ Cropping system } & Year 1 & Year 2 & Year 3 & Year 4 & Year 5 \\
\hline \multicolumn{7}{|c|}{ Rs/man day } \\
\hline Monocrop & 656 & 656 & 65 & 65 & 56 \\
Coconut + pineapple + banana & $(-)$ ve & 1,870 & 1,955 & 1,773 & 941 \\
Coconut + banana & 39 & 1,528 & 1,588 & 1,088 & 650 \\
Coconut + pine apple & $(-)$ ve & 158 & 1,549 & 1,834 & 1,171 \\
Coconut + betel & 177 & 378 & 461 & 320 & 254 \\
Coconut + betel + banana & 198 & 519 & 58 & 404 & 309 \\
Wage rate of an agricultural labour & 104 & 104 & 104 & 104 & 104 \\
\hline
\end{tabular}

Figure 4 Return to labour in different cropping systems

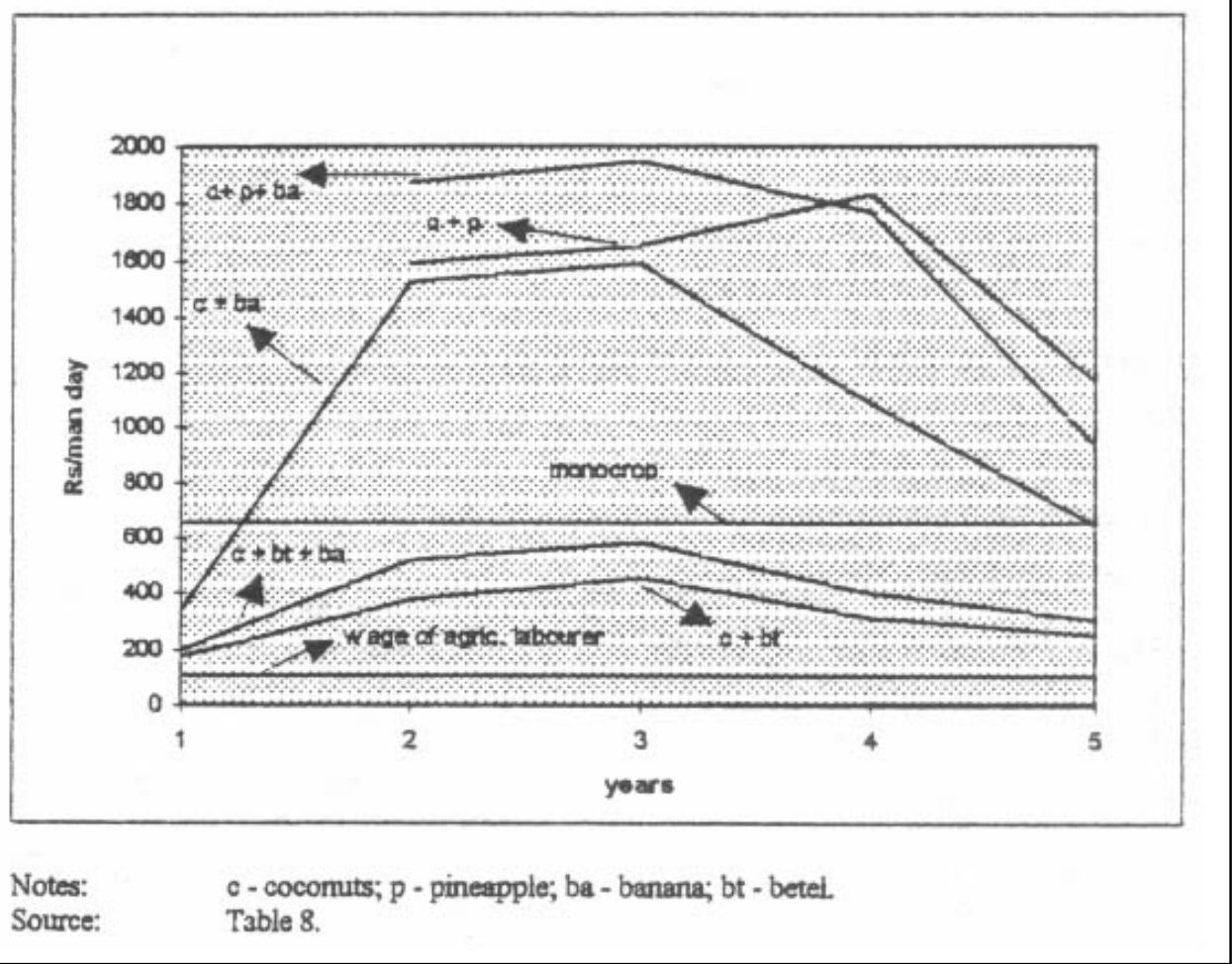

In summary, these results reveal that the return to labor of all the cropping systems analyzed is higher than the wage rate of agricultural laborer. This indicator is particularly high in pineapple and banana systems, although the labor requirements of these crops are also higher. The higher returns to labor of these systems, while utilizing high levels of labor, are mainly due to their higher gross margins. Higher returns to labor of monocrop systems are mainly due to the inherent low labor utilization. The low returns to labor in cropping systems involving betel is not due to higher returns per acre (NPV calculations indicated that betel systems are the highest NPV earners), but due to their much higher labor requirement.

\section{e) Returns to variable costs}

Table 9 and Figure 5 show the returns to variable costs for different cropping systems in different years. 
Table 9. Returns to variable costs in different cropping systems

\begin{tabular}{|l|r|r|r|r|r|}
\hline \multicolumn{1}{|c|}{ Cropping system } & \multicolumn{1}{c|}{ Year 1 } & Year 2 & Year 3 & Year 4 & Year 5 \\
\hline \multicolumn{4}{|c|}{ Returns to variable costs (Rs/rupee invested) } \\
\hline Monocrop & 2.87 & 2.87 & 2.87 & 2.87 & 2.87 \\
Coconut + pineapple + banana & 0.67 & 6.13 & 6.80 & 5.54 & 3.50 \\
Coconut + banana & 1.50 & 5.59 & 5.47 & 4.20 & 3.21 \\
Coconut + pine apple & 0.23 & 5.42 & 6.21 & 5.45 & 3.46 \\
Coconut + betel & 1.35 & 2.19 & 2.54 & 1.89 & 1.61 \\
Coconut + betel + banana & 1.37 & 2.76 & 3.01 & 2.21 & 1.83 \\
\hline
\end{tabular}

Source: Farmer survey, 1985

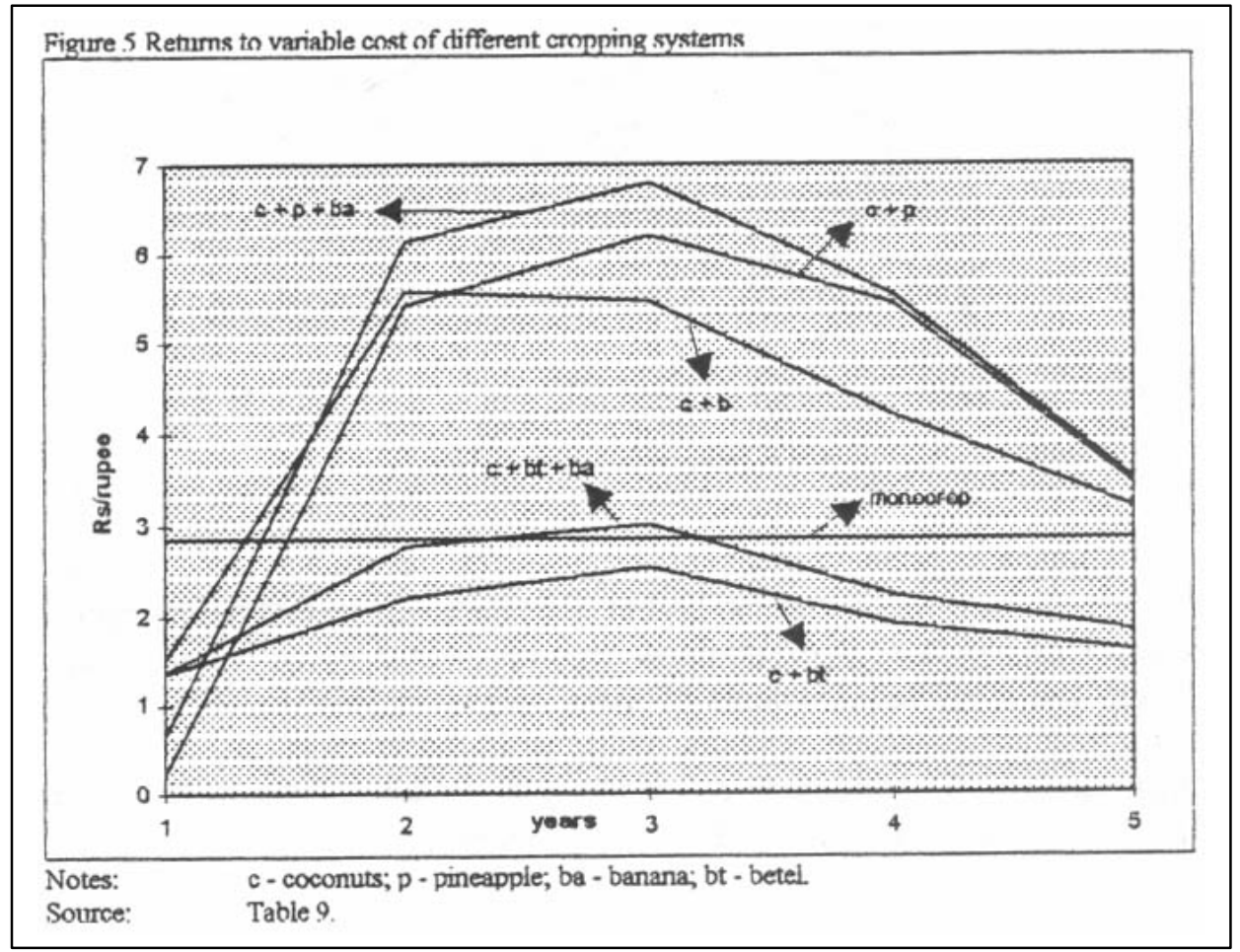

In the first year, all the intercropping systems show a relatively low return to variable costs compared to the monocrop system, which is obviously due to the high cash outlays associated with the intercrop establishment. But from the second year onwards, the coconut + pineapple + banana; coconut + pineapple and coconut + banana systems begin to generate markedly higher returns to variable costs compared to the monocrop system. The interesting feature is that the intercropping systems involving betel always exhibit a tendency to yield low returns to variable costs compared to the monocrop system, except that the coconut + betel + banana system generate a marginally higher returns to variable costs only in the third year. These results suggest that the generation of gross return relative to the utilization of variable costs is higher in pineapple and banana intercropping systems compared to the coconut monocrop system while it is less in betel intercropping systems. The results also indicate that coconut monoculture has an ability to generate higher gross returns relative to the variable costs.

Thus far, the analysis has been confined only to the most prevalent intercropping system found in the survey, and involving semi-perennial intercrops such as pineapple, banana and betel. However, there exists a range of other perennial intercropping systems including crops such as pepper, coffee, cocoa, etc. Although they were not found widely practiced during the survey, they 
deserve comparing with monocrops because their lower abundance was mainly due to the persistence of low market prices for them in recent years ${ }^{5}$. However, farmers expect an increased price for them in years to come.

The main difficulty in comparing perennial intercropping systems with monocrop coconuts arises with regard to the excessive data requirements as perennial intercrops take over ten years to attain the full potential production. For instance, coffee and pepper respectively take 11 and 10 years to reach full production. However, the farmers were unable to provide sufficient accurately remembered data with regard to these intercrops, and this precluded a rigorous comparison with monocrops coconuts. The author has, however, compared a monocrop system with a perennial intercropping system ${ }^{6}$ using six years of actual data, collected from a crop model established in a farmer's field, supplemented with nine years of budgeted data (full details are reported elsewhere, Fernando (1995)). The findings of that comparison may be useful to infer how monocrop coconuts compare with a perennial intercropping system over fifteen years (see Table 10 and Figure 6). The GM of the intercropping system in the first year is less than that of the monocrop system because of the higher costs involved in planting intercrops. It is almost the same as the monocrop system from year 2 to 5 , after which it increases progressively due to the benefits accrued by pepper and coffee as well as the incremental nut yield resulting from the complementary effect of intercropping.

Table 10. Comparison of annual total gross margins (Rs/0.5 ac) of a monocrop system with a perennial intercropping system

\begin{tabular}{|l|r|r|r|r|r|r|}
\hline & \multicolumn{1}{|c|}{ Year 1 } & \multicolumn{1}{|c|}{ Year 2 } & \multicolumn{1}{|c|}{ Year 3 } & \multicolumn{1}{|c|}{ Year 4 } & \multicolumn{1}{|c|}{ Year 5 } & \multicolumn{1}{|c|}{ Year 6 } \\
\hline Monocrop system & 4,019 & 4,747 & 5,949 & 7,910 & 9,660 & 11,350 \\
Intercropping system & 976 & 5,448 & 6,013 & 8,702 & 9,782 & 1,096 \\
\hline
\end{tabular}

\begin{tabular}{|c|c|c|r|r|r|r|r|r|}
\hline Year 7 & Year 8 & Year 9 & Year 10 & Year 11 & Year 12 & Year 13 & Year 14 & Year 15 \\
\hline 15,326 & 17,002 & 18,652 & 20,272 & 21,860 & 23,496 & 25,091 & 26,640 & 23,137 \\
22,983 & 32,072 & 35,960 & 40,945 & 44,616 & 49,049 & 53,530 & 60,422 & 65,741 \\
\hline
\end{tabular}

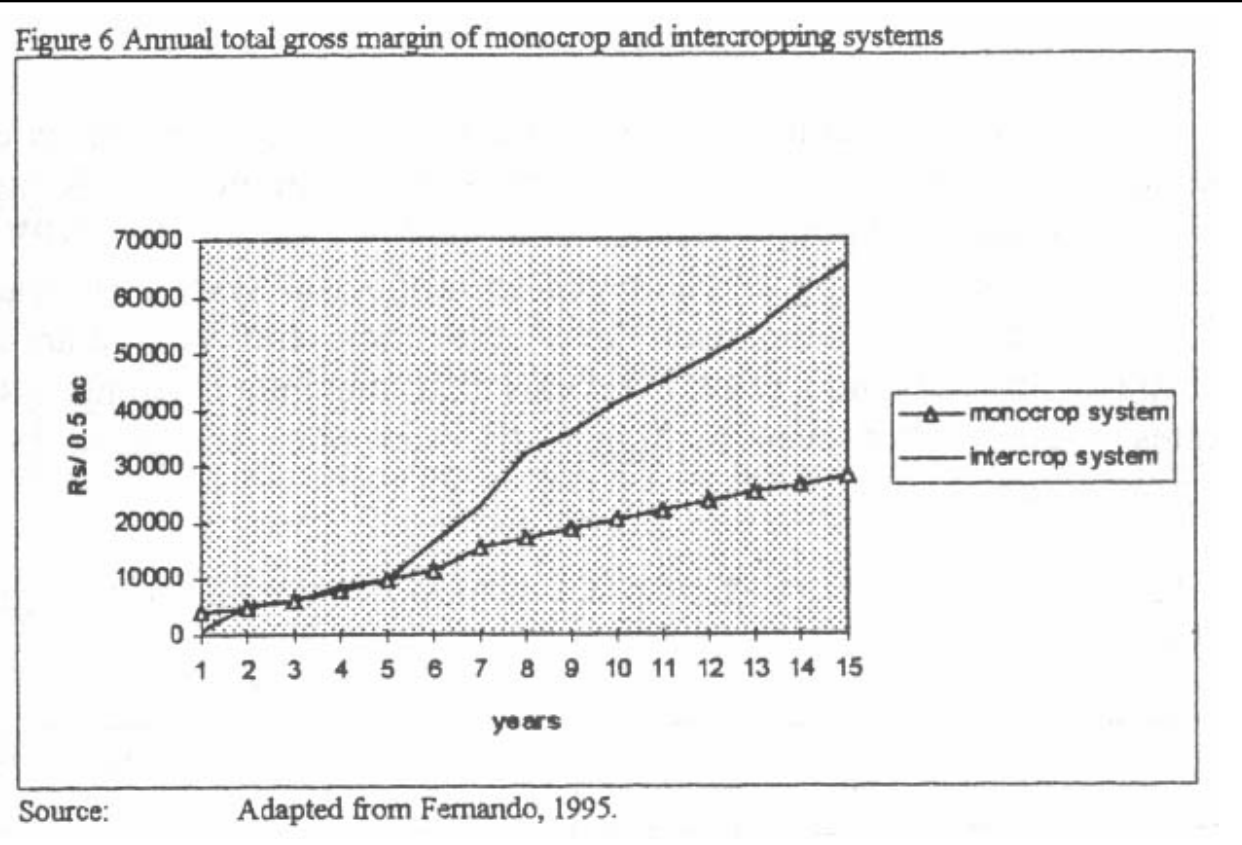

5 A sudden drop in price of these perennial intercrops took place about a decade ago, resulting in a reduction of their widespread growing.

6 This consists of pepper and coffee (ginger was grown only in one year). 
Fernando (1995) has also examined the NPV of the monocrop and intercropping systems, at different discount rates, for two different periods, namely a six-year period of actual data, and a fifteen-year period of actual plus budgeted data (Tables 11 and 12, respectively).

Table 11 Comparison of NPV (Rs/0.5 ac) of monocrop and intercropping systems over six years

\begin{tabular}{|c|c|c|}
\hline Interest rate $(\%)$ & Monoculture system & Intercropping system \\
\hline 5 & 37,609 & 39,795 \\
10 & 32,839 & 34,112 \\
25 & 23,350 & 22,919 \\
30 & 21,230 & 20,446 \\
40 & 17,952 & 16,646 \\
\hline
\end{tabular}

It is clear that the NPV of the perennial intercropping system in the short run (6 years) is higher compared to the monocrop system at low interest rates of $5 \%$ and $10 \%$, but the opposite is the case at higher interest rates.

The NPVs of both monocrop and intercropping systems break even at the $20 \%$ discount rate, above which the NPV of monocrops is higher compared to intercropping system, and below which the NPV of intercropping system is higher compared to monocrop system (Fernando, 1995). However, the comparison over the long run (15 years), as demonstrated by Fernando (1995), reveals that the intercropping system generates higher NPVs even at higher discount rates compared to the monocrop system.

Table 12 Comparison of NPV (Rs/0.5 ac) of monoculture and intercropping systems over 15 years

\begin{tabular}{|c|c|c|}
\hline Interest rate \% & Monoculture system & Intercropping system \\
\hline 10 & 107298 & 183946 \\
25 & 45575 & 66094 \\
30 & 36881 & 50523 \\
40 & 26213 & 32210 \\
\hline
\end{tabular}

Source: Fernando, 1995

These findings confirm that intercropping systems involving perennial intercrops considered generate higher incomes compared to monocrops. However, the returns to labor and variable costs of perennial intercropping system analyzed are less compared to the monocrop system (Fernando, 1995).

Comparison of the results obtained for different economic indicators with respect to coconut monoculture and coconut-based intercropping systems do not provide sufficient evidence to accept the hypothesis that the coconut monoculture systems are economically advantageous than CBI systems. Rather, it provides strong evidence that the intercropping systems are economically advantageous in relation to monocrop system. However, some of the indicators, namely; BCR and returns to variable costs, are reasonably attractive for monocrop coconuts, though they are less than for some intercropping systems. 


\section{SUMMARY}

Coconuts are cultivated predominantly as a monocrop in almost all coconut growing countries, including Sri Lanka. Monocrop coconut use bio-physical resources such as soil, sunlight, etc. sub-optimally. Coconut-based intercropping (CBI) is a strategy to intensify the use of above resources while raising farmers' income. Despite this agronomic promise, the adoption of CBI systems by farmers is as low as $25 \%$ of the agronomically potential area of 100,000 ha notwithstanding the government efforts over 20 years. Economic profitability, albeit not the sole criterion, greatly influences the adoption of new technologies by farmers.

A study was conducted to assess the economics of widely practised five different CBI systems vis-à-vis coconut monocropping. The CBI systems considered were: coconut + pineapple + banana; coconut + banana; coconut + pineapple; coconut + betel; and, coconut + betel + banana. Data were collected by a field survey of 113 coconut-based intercroppers and 37 coconut monocroppers, conducted during March to May 1995 in three main coconut growing districts, namely: Kurunegala; Gampaha; and, Puttalam. Five economic indicators, namely: Total Gross Margin (TGM); Net Present Value (NPV); Benefit-Cost Ratio (BCR); returns to labor; and, returns to capital were employed to test the hypothesis that the coconut monocrooping is economically worthwhile in relation to CBI. The results revealed the following.

- $\quad$ TGM and NPV were markedly higher in all the five intercropping systems analyzed compared to monocrops. However, the CBI systems involving pineapple showed a negative TGM in the first crop year because pineapple does not generate returns to cover the costs in the first year. However, the BCRs were less in three of the five intecropping systems than monocrops.

- Returns to labor of all intercropping systems were greater than the agricultural wage rate.

- Two of the five intercropping systems had lower returns to labor and to variable costs as compared with monocrops, while three of the five intercropping systems had lower BCRs than monocropping.

\section{CONCLUSIONS}

The results obtained for five different economic indicators with regard to coconut monocropping and coconut-based intercropping (CBI) provide strong evidence to prove that CBI systems are economically advantageous vis-à-vis coconut monocropping. Although not the sole criterion, the profitability of an agricultural innovation is a key consideration for its adoption by small farmers. This study has concluded that CBI systems generate higher incomes per unit of land than coconut monocrops. Hence, we argue that the low rate of adoption of CBI is not a problem of low profitability and thus refute the conventionally held view that the low adoption of CBI is tied to low economic profitability of CBI systems. The problem may rest on some other factors, which include: demand for the management of the crop and its inputs, and a skilled knowledge compared to monocropping. These management demands include procuring of: disease-free planting materials; fertilizer; flowering hormones; fiber dust from fiber mills, all with critical timing; hired labor management; etc. The skilled knowledge includes the practical skill of planting different intercrops at different spacing, timely application of flowering hormones for pineapple, harvesting at the right time, disease precaution measures etc. (e.g. soft rot disease in ginger, panama disease in banana, and wilt in pineapple, etc). The risk perception about the innovation being unsuccessful and the risk associated with yield and price outcomes of intercrops appear to be the other factors constraining the adoption of CBI by farmers. Equally, the study thus concludes with emphasizing the need for exploring the influence of above less-frequently addressed factors on adoption of coconut-based intercropping in Sri Lanka. 


\section{ACKNOWLEDGEMENT}

This paper forms a part of a research project (Grant No 12/201/174) funded by the Sri Lanka Council for Agricultural Research Policy (SLCARP). Contribution of Prof. P. Abeygunawardena, Former Head, Department of Agricultural Economics \& Extension, Faculty of Agriculture, University of Peradeniya, in preparing the project proposal is gratefully acknowledged. Unstinted support and cooperation of Dr. R. Mahindapala, Former Executive Director of SLCARP is highly appreciated. The authors are thankful to Dr. Mrs. C. Jayasekara, Acting Director of Coconut Research Institute of Sri Lanka (CRISL), for providing approval to publish this paper. Support of Drs. H. A. J. Gunatileke, K. B. Dassanayake, Mrs. K. V. N. N. Jayalath and Mr S. D. J. N. Subasinghe, all in CRISL is gratefully acknowledged.

\section{REFERENCES}

FAMIYEK, J.A. (1971) Costs and Returns of Rubber and Other Tree Crops on Smallholders' Farms in the Western Region of Ghana. An incomplete paper of the above was obtained through personal communication with Dalton, G.E. (in 1997), SAC, Aberdeen.

FERNANDO, M.T.N. (1997) An economic analysis of factors affecting the adoption of coconutbased farming systems in Sri Lanka. Unpublished Ph.D. Thesis, University of Aberdeen, $445 \mathrm{p}$.

FERNANDO, N. (1995). Economic analysis of coconut-based farming systems in Sri Lanka. Scottish Agricultural Economics Review, 8 107-120

LIYANAGE, M. DE S. (1997). The Coconut Industry in Sri Lanka: Status Report. Country Paper Presented at the International Cashew and Coconut Conference, Dar Es Salaam, Tanzania, 17-21 February, 1997.

LIYANAGE, D.V., WICKRAMARATNE, M.R.T. and JAYASEKARA, C. (1988). Coconut Breeding in Sri Lanka: A Review. Cocos, 6 1-26

NAIR, P.K.R. and BALAKRISHNAN, T.K. (1976) Pattern of Light Utilization by Canopies in a Coconut/Cocoa Crop Combination. Indian Journal of Agricultural Science. 46, 453-462. 
Table A1 Gross margin of ginger cultivation under coconuts (Rs/ac)

\begin{tabular}{|c|c|}
\hline $\begin{array}{l}\text { OUTPUT } \\
\text { Ginger (cwt/ac) } \\
\text { Average price (Rs/cwt) } \\
\text { Income from ginger (Rs/ac) } \\
\text { GROSS RETURN (Rs/ac) }\end{array}$ & $\begin{array}{r}47 \\
1,325 \\
62,805 \\
62,805 \\
\end{array}$ \\
\hline $\begin{array}{l}\text { INPUTS } \\
\text { Labor use (md/ac) } \\
\text { Land clearing } \\
\text { Land preparation } \\
\text { Dipping in chemicals } \\
\text { Planting } \\
\text { Fertilizer application } \\
\text { Mulching } \\
\text { Weeding } \\
\text { Harvesting } \\
\text { Application of insecticide } \\
\text { Processing } \\
\text { Total labor use (md/ac) } \\
\text { Wage rate (Rs/md) } \\
\text { Labor cost (Rs/ac) }\end{array}$ & $\begin{array}{r}5 \\
11 \\
4 \\
8 \\
6 \\
8 \\
23 \\
22 \\
5 \\
30 \\
119 \\
104 \\
\text { * }\end{array}$ \\
\hline $\begin{array}{l}\text { Materials } \\
\text { Seed singer (cwt.ac) } \\
\text { Price of seed ginger } \\
\text { Seed ginger cost (Rs/ac) } \\
\text { Fiber dust-number of } 4 \text { WT/ac } \\
\text { Price per } 4 \text { WT (Rs) } \\
\text { Cost of fiber dust (Rs/ac) } \\
\text { Inorganic fertilizer (kg/ac) } \\
\text { Average price (Rs/kg) } \\
\text { Cost of inorganic fertilizer (Rs/ac) } \\
\text { Cost of insecticide \& fungicides (Rs/ac) } \\
\text { Total material cost (Rs/ac) } \\
\end{array}$ & $\begin{array}{r}9 \\
1,450 \\
13,746 \\
45 \\
95 \\
4,237 \\
450 \\
10 \\
4,343 \\
768 \\
23,094 \\
\end{array}$ \\
\hline $\begin{array}{l}\text { Transport } \\
\text { Fiber dust - number of 4WT } \\
\text { Ave. cost for transport one 4WT (Rs) } \\
\text { Fiber dust transport cost (Rs/ac) } \\
\text { Planting materials transport } \\
\text { Fertilizer } 1 \text {-transport cost (Rs/ac) } \\
\text { Fertilizer } 2 \text { - transport cost (Rs/ac) } \\
\text { Total transport cost (Rs/ac) }\end{array}$ & $\begin{array}{r}45 \\
139 \\
6,199 \\
193 \\
256 \\
100 \\
6,748 \\
\end{array}$ \\
\hline $\begin{array}{l}\text { Machinery } \\
\text { Land preparation (Rs/ac) } \\
\text { Variable costs total (Rs/ac) } \\
\text { GROSS MARGIN (Rs/ac) }\end{array}$ & $\begin{array}{r}1,570 \\
31,412 \\
31,393\end{array}$ \\
\hline
\end{tabular}

Notes: Errors in sums are due to rounding

1 Sterling pound is approximately Rs 95 in July 1997

$1 \mathrm{cwt}=112$ pounds $(50 \mathrm{~kg}) \mathrm{md}$ - man-days

* labor was not valued, 4WT - four-wheel tractor

Source: Farmer survey, 1995 
Table A2 Gross margin of banana cultivation under coconuts (Rs/ac)*

\begin{tabular}{|c|c|c|c|c|c|}
\hline & & & Years & & \\
\hline OUTPUT & 1 & 2 & 3 & 4 & 5 \\
\hline Bunches/ac & 122 & 180 & 177 & 151 & 146 \\
\hline Average price (Rs/bunch & 154 & 143 & 130 & 107 & 73 \\
\hline Income from bunches (Rs/ac) & 18,788 & 25,740 & 23,010 & 16,157 & 10,658 \\
\hline Suckers & 240 & 300 & 234 & 271 & 350 \\
\hline Average price (Rs/sucker) & 13.22 & 13.22 & 13.22 & 13.22 & 13.22 \\
\hline Income from suckers (Rs/ac) & 3,173 & 3,966 & 3,093 & 3,583 & 4,627 \\
\hline Gross return (Rs) & 21,961 & 29,706 & 26,103 & 19,740 & 15,285 \\
\hline INPUTS & & & & & \\
\hline Labour (md/ac) & & & & & \\
\hline Land cleaning & 6 & & & & \\
\hline Land preparation & 5 & & & & \\
\hline Cutting pits & 7 & & & & \\
\hline Dipping in chemicals & 1 & & & & \\
\hline Planting & 3 & & & & \\
\hline Fertilizer application & 4 & 4 & 4 & 4 & 4 \\
\hline Fiber dust mulching & 4 & & & & \\
\hline Weeding & 6 & 6 & 5 & 5 & 6.5 \\
\hline Removal of suckers & 2 & 4 & 4 & 5.5 & 11 \\
\hline Application of insecticide & 1 & & & & \\
\hline Removal of old banana logs & & 3 & 1 & 1 & \\
\hline Harvesting & 2 & 2 & 2 & 3.5 & 6 \\
\hline Total md/ac & 41 & 19 & 16 & 19 & 27.5 \\
\hline $\begin{array}{l}\text { Wage rate }(\mathrm{Rs} / \mathrm{md}) \\
\text { Labour cost }{ }^{* *}\end{array}$ & 104 & 104 & 104 & 104 & 104 \\
\hline Materials & & & & & \\
\hline Number of suckers & 158 & & & & \\
\hline Average price (Rs/sucker) & 13.22 & & & & \\
\hline Cost of suckers (Rs/ac & 2089 & & & & \\
\hline Fiber dust (number of $4 \mathrm{WTs}$ ) & 35.5 & & & & \\
\hline Price per 4WT (Rs) & 69 & & & & \\
\hline Cost of fiber dust (Rs/ac) & 2,444 & & & & \\
\hline Inorganic fertilizer (Rs/ac) & 211 & 221 & 224 & 239 & 223 \\
\hline Average price (Rs.kg) & 8.5 & 8.5 & 8.5 & 8.5 & 8.5 \\
\hline Cost inorganic fertilizer (Rs/ac) & $1,793.5$ & $1,878.5$ & 1,904 & $2,031.5$ & $1,895.5$ \\
\hline Cost insecticides and fungicides (Rs/ac) & 274 & 215 & & & \\
\hline Total material cost (Rs/ac) & 6,600 & $2,093.5$ & 1,904 & 2,031 & $1,895.5$ \\
\hline Transports cost & & & & & \\
\hline Number of $4 \mathrm{WTs}$ of fiber dust & 35.5 & & & & \\
\hline Average cost for transport/one load of $4 \mathrm{WT}$ & 152 & & & & \\
\hline Fiber dust transport cost (Rs/ac) & 5,396 & & & & \\
\hline Planting materials transport cost (Rs/ac) & 238 & & & & \\
\hline Fertilizer transport cost (Rs/ac) & 121.75 & 121.75 & 121.75 & 121.75 & 121.75 \\
\hline Total transport cost (Rs/ac) & $5,755.75$ & 121.75 & 121.75 & 121.75 & 121.75 \\
\hline Machinery & & & & & \\
\hline Land preparation (Rs/ac) & 1,415 & & & & \\
\hline Total machinery cost (Rs/ac) & 1,415 & & & & \\
\hline Total variable cost (Rs/ac) & 13,771 & 2,215 & 2,026 & 2,153 & 2,017 \\
\hline Gross Margin (Rs/ac) & 8,190 & 27491 & 24078 & 17586 & 13268 \\
\hline
\end{tabular}


Trable A3 Groes margin of pineapple cultivation under cocoouta (Res ac)"

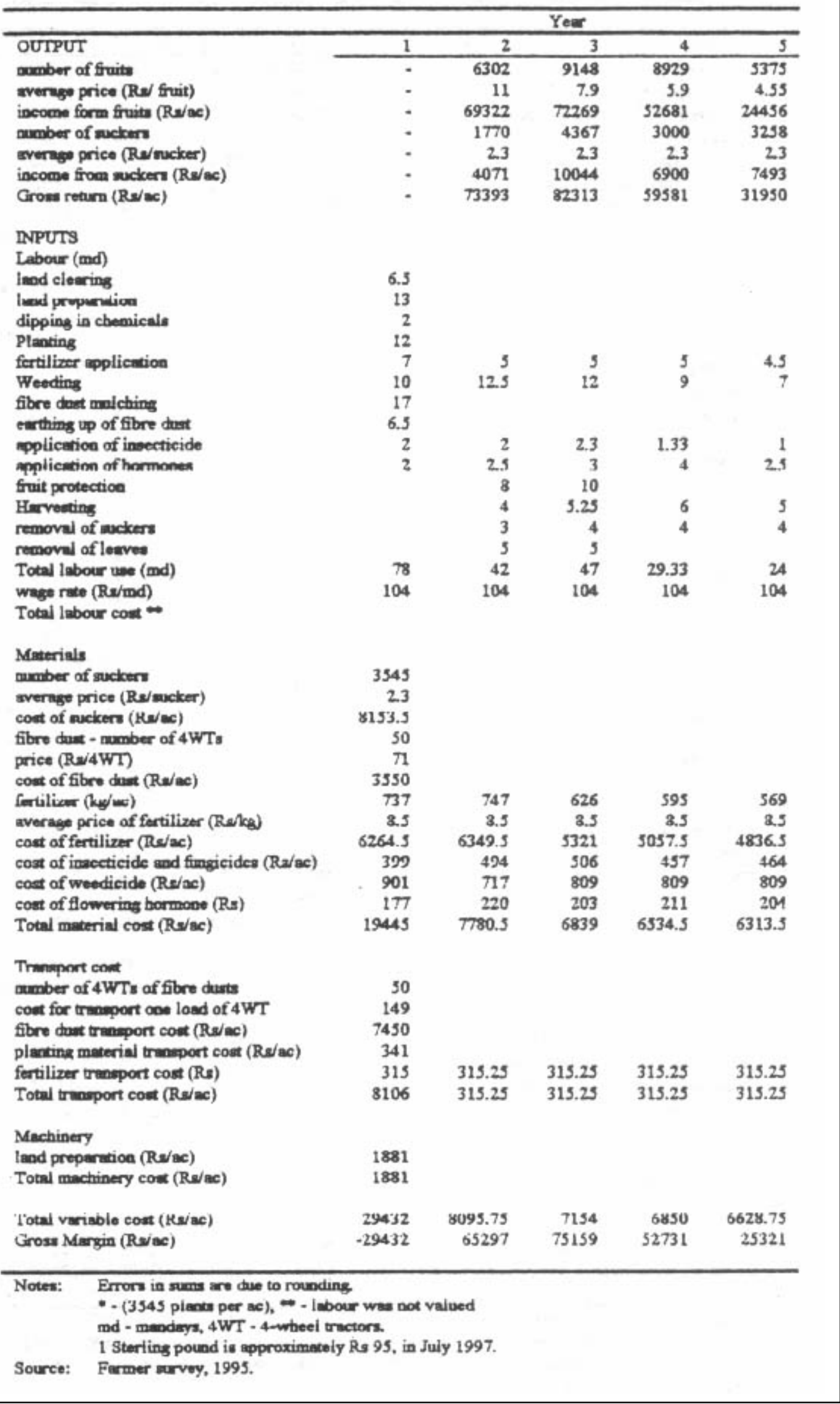




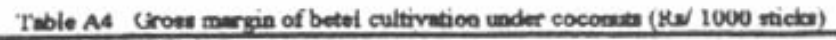

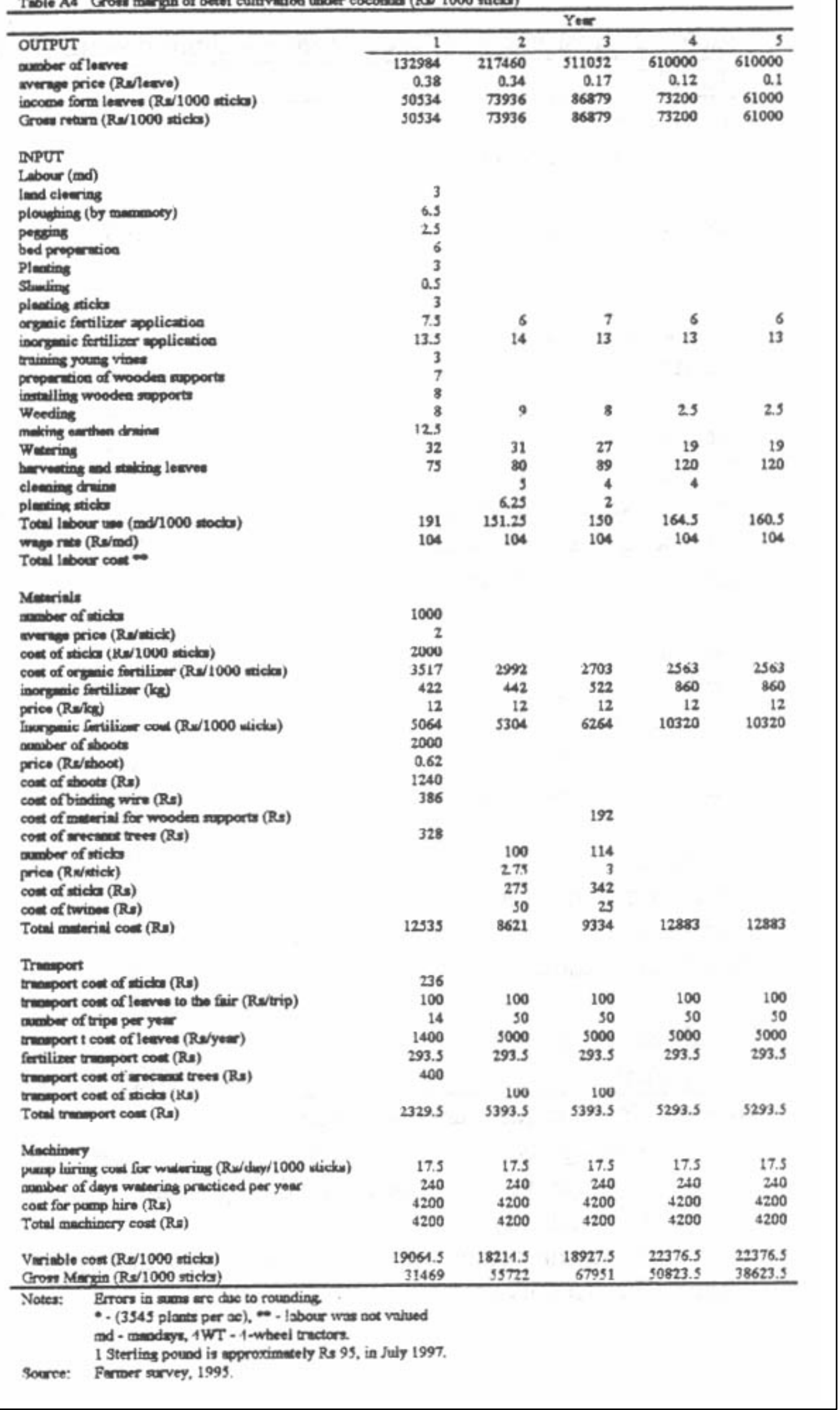


Table A5 Gross margin of coconut monoculture systems (Rs/ac)

\begin{tabular}{|l|r|}
\hline OUTPUT & \\
\hline No of nuts per year & 2,946 \\
Average price (Rs/nut) & 3.16 \\
Cross Return (Rs) & 9,309 \\
INPUTS & \\
Labour use (in md) & 6 \\
Weeding & 3 \\
Fertilizer application & 3 \\
nut collection & 11 \\
Total and & 0 \\
Average wage rate(Rs/day) & 582 \\
Harvesting (Rs contract labour) & 582 \\
Sub Total 1 -labour cost (Rs) & \\
Materials cost (Rs) & 125 \\
Fertilizer (kg/ac) & 9 \\
price (Rs/kg) & 1,063 \\
Fertilizer cost (Rs) & 1,063 \\
Sub Total 2 - mareials cost (Rs) & \\
Transport cost & 208 \\
Fertilizer transport (Rs) & 238 \\
internal field transportation of coconut (Rs) & 446 \\
Sub Total 3 - transport cost (Rs) & 2,091 \\
Variable costs (Rs/ac) & 7,219 \\
CM (R.--,/ac) & \\
\hline
\end{tabular}

Notes: Errors in sums are due to rounding.

Average age of coconut palms $=41$ years.

Average number of bearing palms per acre $=64 \mathrm{md}$-mandays.

1 Sterling pound is approximately Rs 95, in July 1997. Source: Farmer survey; 1995. 
Table A6

\begin{tabular}{|c|c|c|c|c|c|c|}
\hline i) & \multicolumn{6}{|c|}{ Computation of NPV (Rs/ac) of the coconut monoculture systems } \\
\hline & & Year 1 & Year 2 & Year 3 & Year 4 & Year 5 \\
\hline \multicolumn{2}{|c|}{ Gross margin (Ra/ac) } & 6074.86 & 6074.86 & 6074.86 & 6074.86 & 6074.86 \\
\hline & \multicolumn{6}{|c|}{ NPV of five years of GM (at $15 \%$ interest rate) $=$ Rs 20363.8 per acre } \\
\hline & \multicolumn{6}{|c|}{ NPV of five years of GM (at $20 \%$ interest rate) $=$ R9 18168.0 per acre } \\
\hline & \multicolumn{6}{|c|}{ NPV of five years of GM (at $25 \%$ interest rate) = Rs 16337.0 per acre } \\
\hline \multirow[t]{2}{*}{ ii) } & \multicolumn{6}{|c|}{ Computation of $\mathrm{B} / \mathrm{C}$ ratio of the coconut monoculture systems } \\
\hline & \multicolumn{6}{|c|}{$\mathrm{B} / \mathrm{C}$ ratio $=9309.36 / 3234.5=2.87814$} \\
\hline \multirow[t]{5}{*}{ iii) } & \multicolumn{6}{|c|}{ Computation of returns to labour } \\
\hline & \multicolumn{5}{|c|}{ - cost ${ }^{*}$ of non-labour inputs (RR/ac) } & $2,090.5$ \\
\hline & \multicolumn{5}{|c|}{ - gross return less cost of non-labour inputs (Rs/ac) non-labour inputs (Re/ac) } & $7,218.86$ \\
\hline & \multicolumn{5}{|c|}{ - total labour use (md/ac/year) } & 11 \\
\hline & \multicolumn{5}{|c|}{ Returns to labour (Rs/md) } & 656.26 \\
\hline \multirow[t]{5}{*}{ iv) } & \multicolumn{6}{|c|}{ Computation of returns to variable costs } \\
\hline & \multicolumn{5}{|c|}{ Total farm variable cost (RS/ac) } & $3,234.5$ \\
\hline & \multicolumn{5}{|c|}{ Gross return (Rs/ac) } & $9,309.36$ \\
\hline & \multicolumn{5}{|c|}{ Returns to variable cost } & 2.87814 \\
\hline & \multicolumn{6}{|l|}{ (Rs/Rupee) } \\
\hline
\end{tabular}

Notes: * - contract labour cost was also included, and - tuna day, 1 Sterling pound was approximately Rs 95, in July 1997.

Source: Farmer survey, 1995. 


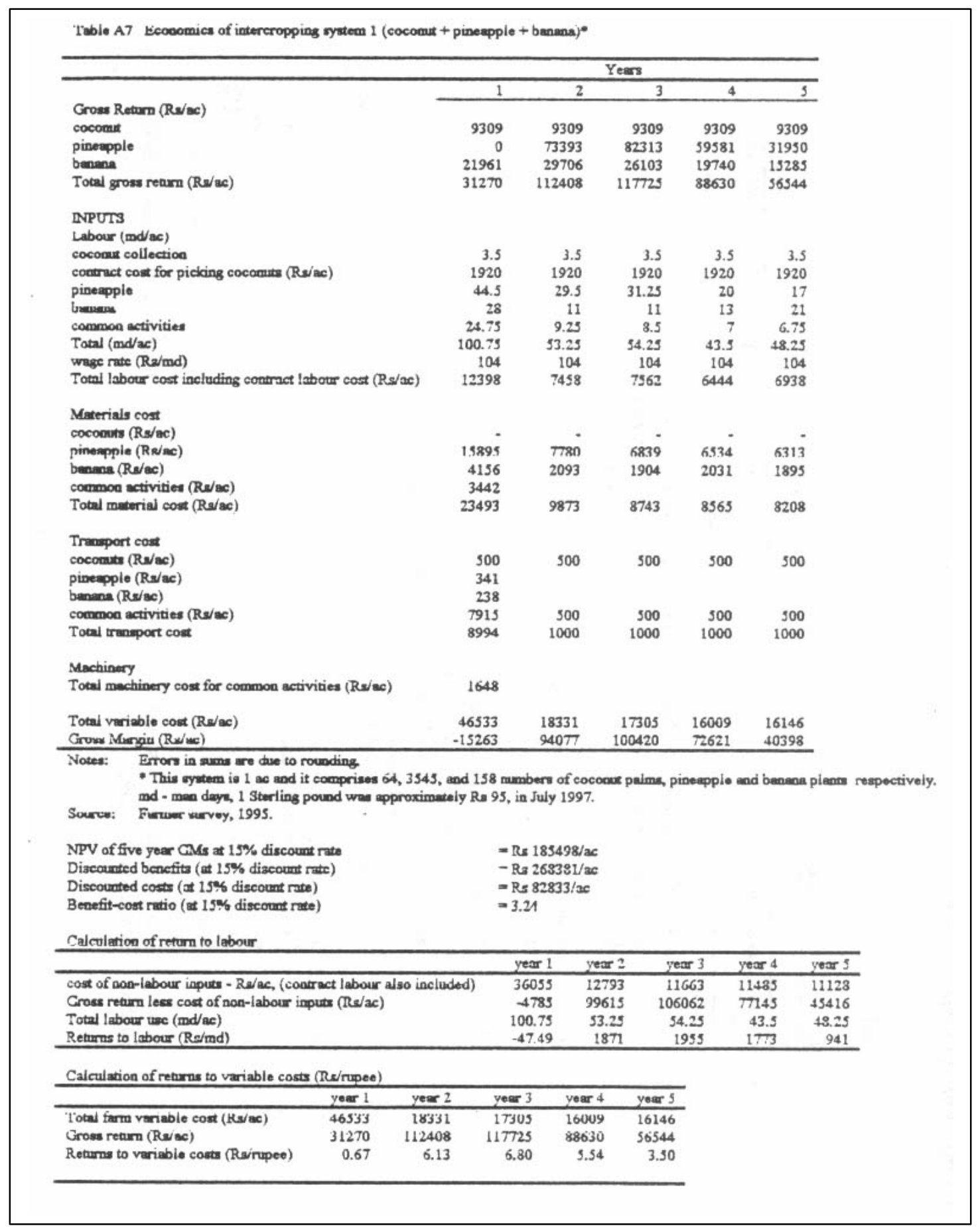


Tabie Ar ticonomics of intercropping system 2 (coconst + banana)

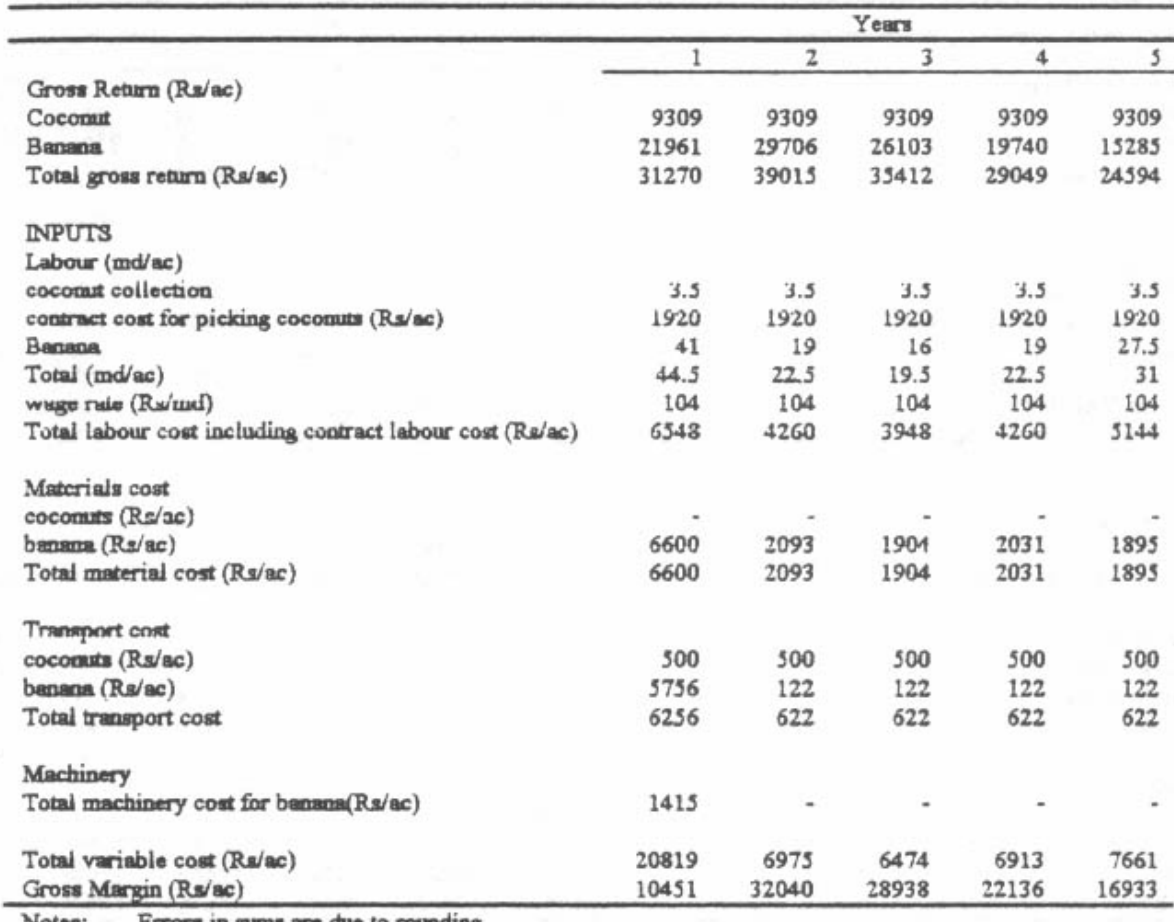

Notes: Errors in sums are due to rounding

- This system is 1 ac and it comprises 64 and 158 numbers of coconut paims and banana plants respectively. md - man days, 1 Sterling pound was approximately Rs 95, in July 1997.

Source: Farmer survey, 1995.

NPV of 5 year GM 5 as $15 \%$ discount rate

Viscounted benefits (at $15 \%$ diseoum rate)

Discounted costs (a 15\% discount rase) $\quad-$ Rs 35396/ac

Benofit-cost ratio (at $15 \%$ discount rate) $\quad=3.07$

Calculation of rolum to labour

\begin{tabular}{lrrrrr}
\hline & year 1 & year 2 & year 3 & year 4 & year 5 \\
\hline cost of non-iabour imputs - Re/ac, (contract labour aiso inciuded) & 16191 & 4635 & 4446 & 4573 & 4437 \\
Gross return less cost of non-labour inputa (Rs/ac) & 15079 & 34380 & 30966 & 24476 & 20157 \\
T'otal labour use (md/ac) & 44.5 & 22.5 & 19.5 & 22.5 & 31 \\
Resurns to labour (Rs/md) & 338.85 & 1528 & 1588 & 1087 & 650 \\
\hline
\end{tabular}

Calculation of returma to variable costa (Rsirupee)

\begin{tabular}{lrrrrr}
\hline \multicolumn{6}{l}{ Calculation of returns to variable costs (Rs/rupee) } \\
\hline & year 1 & year 2 & year 3 & year 4 & year 5 \\
\hline Total farm variable cost (Rs/ac) & 20819 & 6975 & 6474 & 6913 & 7661 \\
Gross return (Rs/ac) & 31270 & 39015 & 35412 & 29049 & 24594 \\
Returns to variable costa (Rsirupee) & 1.50 & 5.59 & 5.47 & 4.20 & 3.21 \\
\hline
\end{tabular}


Table Aง Economics of intercropping system 3 (cocomis + pineapple)

\begin{tabular}{|c|c|c|c|c|c|}
\hline \multirow[b]{3}{*}{ Gross Return (Rs/ac) } & \multicolumn{5}{|c|}{ Years } \\
\hline & 1 & 2 & 3 & 4 & 5 \\
\hline & & & & & \\
\hline Coconut & 9309 & 9309 & 9309 & 9309 & 9309 \\
\hline Pineapple & 0 & 73393 & 82313 & 59581 & 31950 \\
\hline Total gross return (Ra/ac) & 9309 & 82702 & 91622 & 68890 & 41259 \\
\hline \multicolumn{6}{|l|}{ INPUTS } \\
\hline \multicolumn{6}{|l|}{ Labour (md/ac) } \\
\hline cocomit collection & 3.5 & 3.5 & 3.5 & 3.5 & 3.5 \\
\hline contract cost for picking coconuts & 1920 & 1920 & 1920 & 1920 & 1920 \\
\hline Pineapple & 78 & 42 & 46.25 & 29 & 24 \\
\hline Tolad (mol/wac) & 81.5 & 45.5 & 49.75 & 32.5 & 27.5 \\
\hline wage rate (Re/md) & 104 & 104 & 104 & 104 & 104 \\
\hline Total labour cost including contract labour cost ( $\mathrm{R} 3 / \mathrm{ac})$ & 10396 & 6652 & 7094 & 5300 & 4780 \\
\hline \multicolumn{6}{|l|}{ Materials cost } \\
\hline cocomuts (Re/sc) & - & - & $\cdot$ & - & - \\
\hline pineapple (Rs/ac) & 19337 & 7780 & 6839 & 6534 & 6313 \\
\hline Total material cost (Rs/ac) & 19337 & 7780 & 6839 & 6534 & 6313 \\
\hline \multicolumn{6}{|l|}{ Transport cost } \\
\hline cocomuts (Re/ac) & 500 & 500 & 500 & 500 & 500 \\
\hline pineapple (Rs/ac) & 8256 & 315 & 315 & 315 & 315 \\
\hline Total transport cost & 8756 & 815 & 815 & 815 & 815 \\
\hline \multicolumn{6}{|l|}{ Machinery } \\
\hline Total machinery cost for pineapple ( $\mathrm{Rs} / \mathrm{ac}$ ) & 1881 & & & & \\
\hline Total variable cost (Rs/ac) & 40370 & 15247 & 14748 & 12649 & 11908 \\
\hline Gross Margin (Re/ac) & -31061 & 67455 & 76874 & 56241 & 29351 \\
\hline
\end{tabular}

Notes: Errors in sums are due to rounding.

- This system is 1 ac and it comprises 64 and 3545 numbers of coconur paims and pineapple plants respectively.

Source: Farmer survey, 1995.

NPV of five year (iM a at $15 \%$ discount rate

Discounted benefits (at 15\% discoum rate)

Discounted costs (at $15 \%$ discount rase)

Benefit-cost ratio (at $15 \%$ discount rate)

$121291 / a c$

- Rs 190773/ac

$=\operatorname{Rs} 69483 / \mathrm{aC}$

$=2.74$

Calculation of retum to labour

\begin{tabular}{lrrrrr}
\hline & year 1 & year 2 & year 3 & year 4 & year 5 \\
\hline cont of non-iabour inpuss - Ke/ac, (contract labour also inctuded) & 31894 & 10515 & 9574 & 9269 & 9048 \\
Gross return less cost of non-iabour imputs (Rs/ac) & -22585 & 72187 & 82048 & 59621 & 32211 \\
Total labour use (md/ac) & 81.5 & 45.5 & 49.75 & 32.5 & 27.5 \\
Returns to labour (Ra/md) & -277 & 1586 & 1649 & 1834 & 1171 \\
\hline
\end{tabular}

Returns to labour (Raimd)

Calcuiation of renurns to variable costs (Rsirupee)

\begin{tabular}{lrrrrr}
\hline & year 1 & year 2 & year 3 & year 4 & year 5 \\
\hline Total farm variabie cost (Rs/ac) & 40370 & 15247 & 14748 & 12649 & 11908 \\
Gross return (Rs/ac) & 9309 & 82702 & 91622 & 68890 & 41259 \\
Returns to variabie costs (Rs/rupee) & 0.23 & 5.42 & 6.21 & 5.45 & 3.46 \\
\hline
\end{tabular}




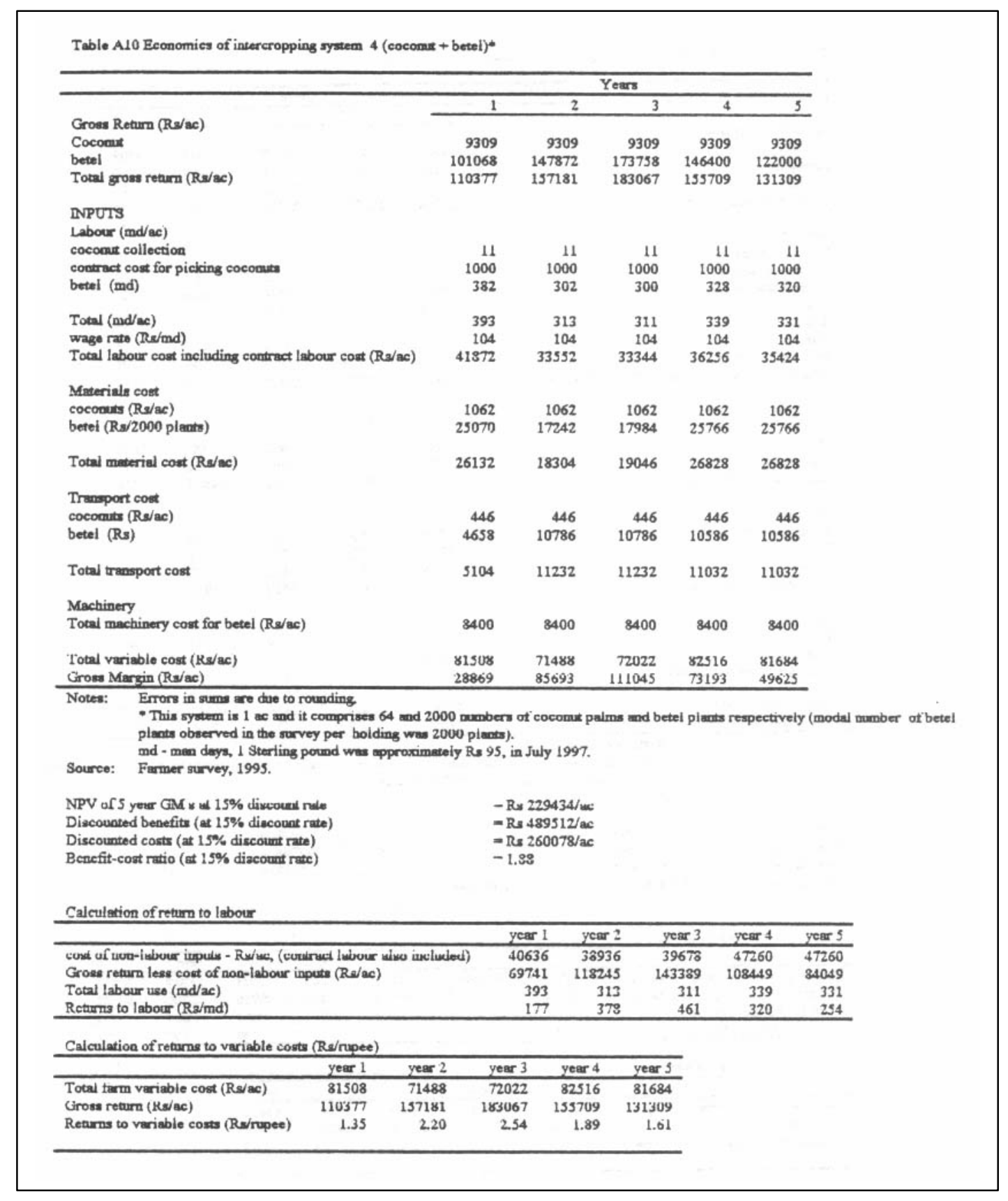




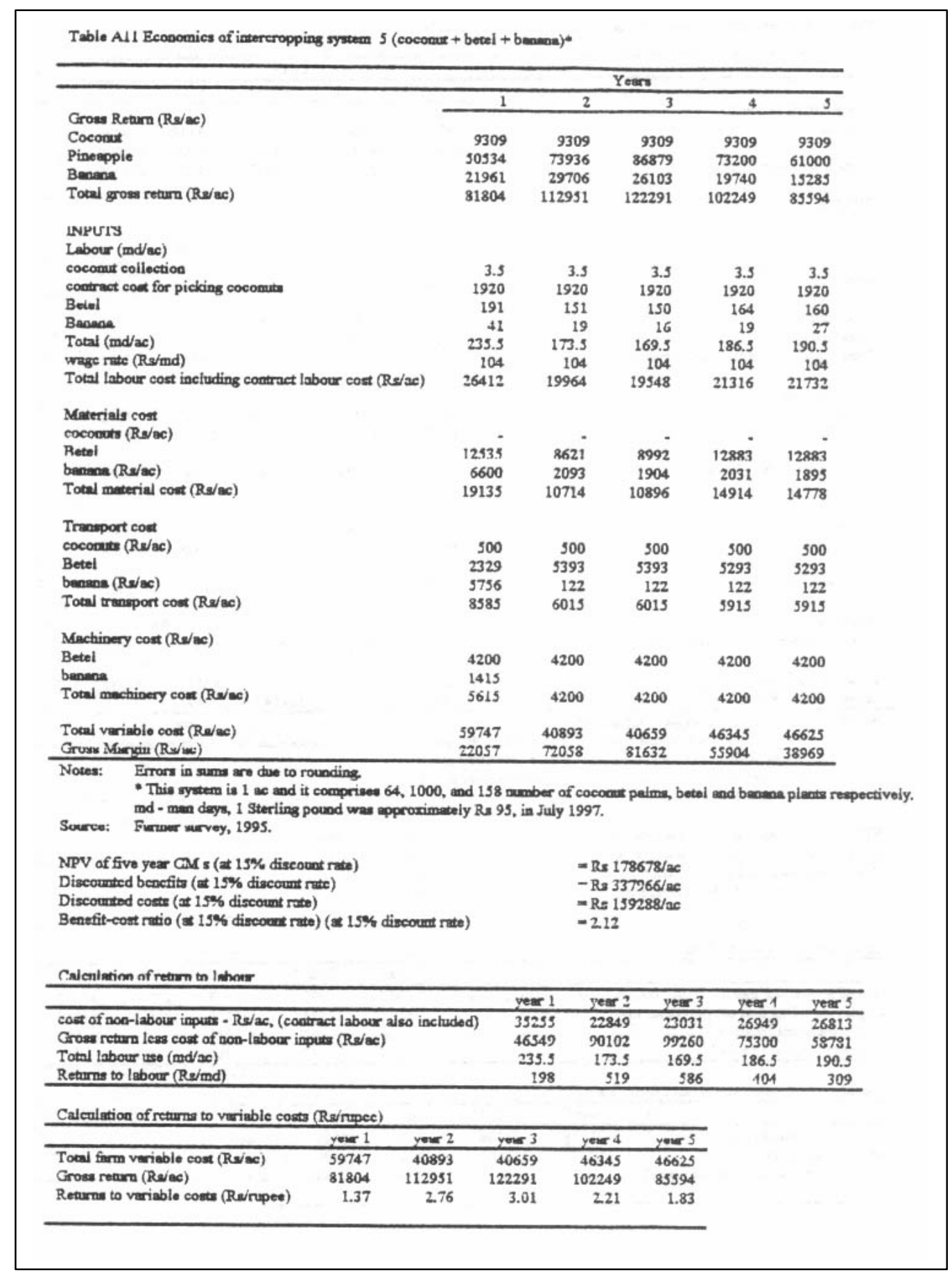

